$$
\begin{aligned}
& \text { 震 }
\end{aligned}
$$

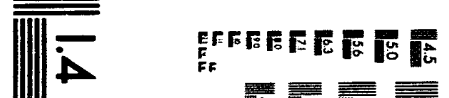

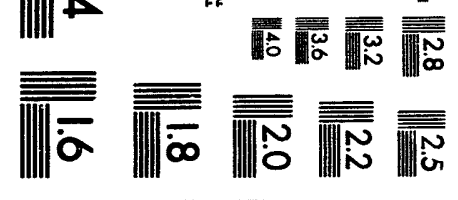




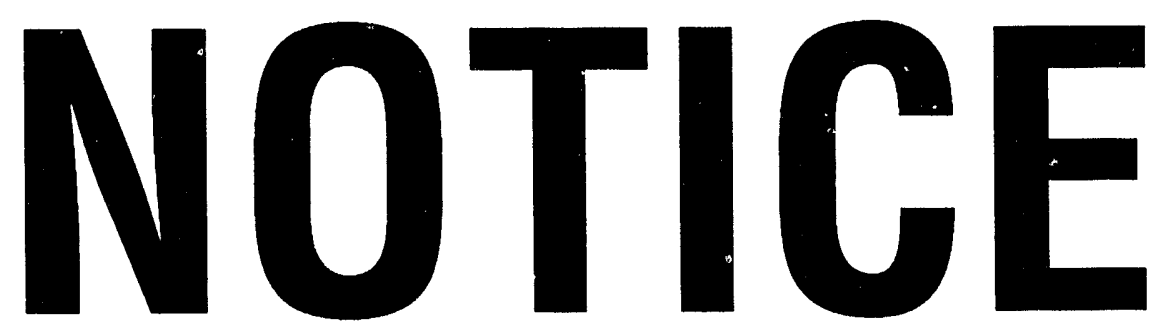

\section{GERTAN DATA}

\section{GONTAINED IN THS}

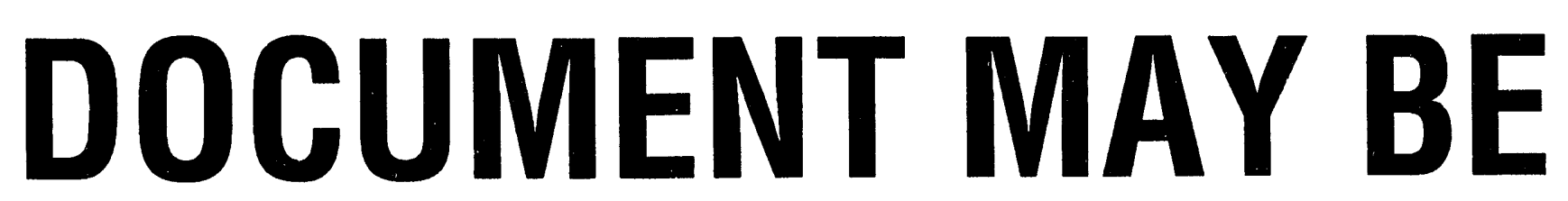

\section{DIFFICULT TO READ}

IN MICROFICHE

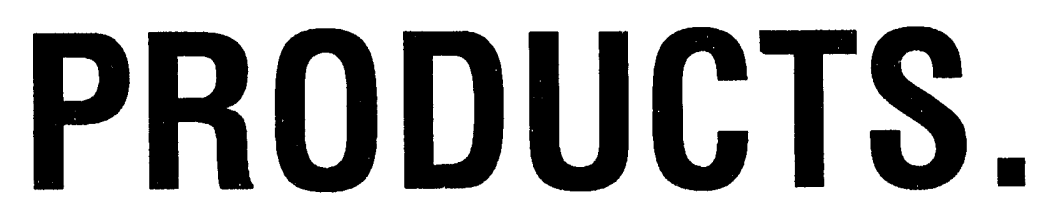


N.C. Jaitly, M.D. Colemant, and A. Ramus

Balbon Diviston, Maxwel! Laborabories. Inc.

8888 Balbon Ave.

San Diego, CA 92123

AND

L.M. Earley, J.N. Downine, H.H. Reisch, L.D. Caudill, and S.A. Eversoi Los Alamos Nationel Laboratory. Group M-4, MS P942 P.O. Box 1663

Los A!amos. NM 87545

\section{RECEIVED}

JAN 271994 OSTI

\section{ABSTRACT}

The DARHT Facility is being designed a Los Alamos Nitional Laboratory to produce high resolition flash radiographs of hydrodynamic experiments. Two linear induction accelerators (LIA), exch in the range of 16 to $20 \mathrm{MeV}$, will be used to produce intense bremsstrahlung X-ray pulses of shor duration (60 ns flat (op). Each LiA will produce a $3 \mathrm{kA}$, high brighiness, electron keam using $4 \mathrm{MeV}$ injector and series of $250 \mathrm{kV}$ induction cells. Technology demonstrapion of key accelerator subsystems is under progress at the DARHT Integrated Tent Stand (ITS). The eight inductions ce!ls present in the ITS are driven by a Maxweli prototype Induction Cell Puised Power Supply (ICPFS) which provides $250 \mathrm{kV}, 70$ ns pulses via four Blumleins. Each Blumlein drives two cells and is triggered using independently controlied trigger units. This turnkey DARHT Trigget System, consisting of four separate trigger units, provides $200 \mathrm{kV}$ trigger pulses with low jitter and fast rise time to each of the four Blumlein coexial spark gaps. Details of the irigger system design and results obuined during exiensive iesting at Maxwell are dascrited

\section{NTRODLCTION}

The tumkey DARHT Trigger System consists of a single control console which controls four independent vigger units. The console is 6 feet high and made up of two 19 inch rack mount cabinets bolted side-by-side. The trigger unit enclosures, each 33 inch wide by 39 inch long by 46 inch high, are located 100 feet from the control cunsole. The Trigger System peformance specifications, as demonstrated during the acceptance testing, are stummarized in Table 1 .

The key components of the trigger system are deseribed below.

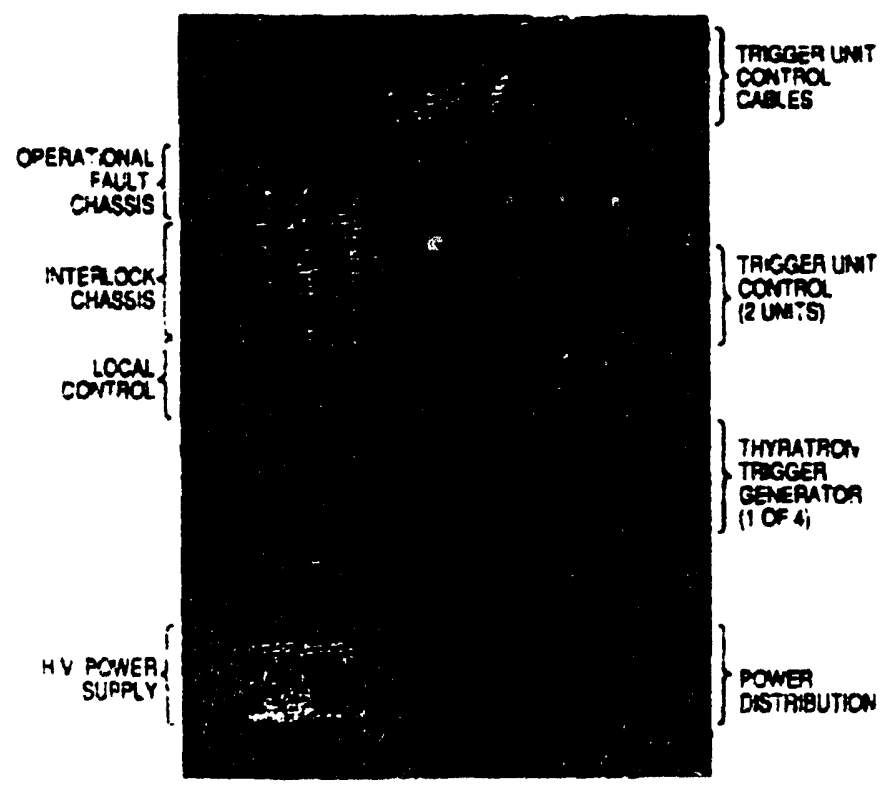

Fig. I DARHT Trigger System Control Corsole
Table 1. DARHT Trigger System Test Results
Peak Output Volage
Puise Polerity
Opemating Voliage
Pulse Rep-Rate
Major Componen: Life

Pulse Fal: time

(10\% :0 90\%)

Triget Sysiem Jit!ex ineasurec itom ccrutrol room low vitage vigget to HV ou(pus)

\section{Dift in Ouiput Pulse Timing \\ Trigger System Pre-fire and No.Fire Rats:}

Palse Shot-10-Sho: Reproducibility (30)

Losc

Input Power:

Thyratron Dual-Pulse Generntor and Supplies HVPS

\author{
70 to $220 \mathrm{kV}$ adjustat!e \\ Negative \\ $200 \mathrm{xV}$ max. (into matched load) \\ Single shot $100.2 \mathrm{~Hz}$ \\ $>10^{7}$ charge/dixcharge cycles \\ < $14 \mathrm{~ns}$ for output above $150 \mathrm{kV}$ \\ (measured as $67 \Omega$ sable input) \\ < 275 ps (1 o), and \\ < 1.5 ns peak-10-peak \\ (based on any 100 consecutive \\ rese shots)

\section{$-4 \mathrm{~ns}$ in 2000 consecoutive shors at $0.2 \mathrm{~Hz}$}

No pre-fires or no-fires in $\$ 0000$ consecutive shots

$5 \pm 2.5 \%$ of mean peak amplinule

$67 \Omega$ cable (30 feet) connected 10 coaxial spark gap via matching iemination

120 V. 10. is A, regulation $\pm 1 \%$

208 V. 30. 15 A, unrequlated

\section{IRICGER SYSTEMCONTROL CONSOLE}

The control systern design allows independent creration of one, uil. or any combination of the four independent trigger units. Trigger sysiem controls are based on: $24 \mathrm{~V}$ relay logic. Operation in the LOCAL NODE is carried out from the control console front paneis as shown in Figure 1. In the REMOTE MODE trigger units are operated and monitored vis a MODICON programmable logic controller through isolated relay contacts.

The system controls incorporate protection circuits which monitor out-of-range thytatron cathode and rese:voir heater de voltages. Digital panel meters display all heater voitages and curretits along with charge voltage for each trigges unit. Also monitured are thyratron discharge over-current and condition of pre-fire/no-fire. Protec:ion circuits also monitor the dc reset current and palse shapener output overvoltage. A number of other system and safety istreslocks are provided for safe operation. Linder a fault condition ine Trigger System high voltage is uutomatica!ly inhibized and the type of faule displayed via indicators on the front panels. isoiated reiay contacts provide various uperational/fault status conditions of the system to REMOTE. All safely and operation fault interlocks are latching in nature, and must be manually reset (after fauli conditions are sleared) before operation can be resumed.<smiles>C=CC</smiles> 


\section{DISCLAIMER}

This report was prepared as an account of work sponsored by an agency of the United States Government. Neither the United States Government nor any agency thereof, nor any of their employees, makes any warranty, express or implied, or assumes any legal liability or responsibility for the accuracy, completeness, or usefulness of any information, apparatus, product, or process disclosed, or represents that its use would not infringe privately owned rights. Reference herein to any specific commercial product, process, or service by trade name, trademark, manufacturer, or otherwise does not necessarily constitute or imply its endorsement, recommendation, or favoring by the United States Government or any agency thereof. The views and opinions of authors expressed herein do not neciessarily state or reflect those of the United States Government or any agency thereof. 
The console houses a compace $2 \mathrm{~kJ} / \mathrm{s}$ Maxwell switching power supply. This is a noasundard. $70 \mathrm{kV}$ (four outpits), versicn of Maxwell's CCDS powe: supply prodoct tine. This powe supply, specufically derigned for the DARHT Triger System, charges a single trigget unit in $56 \mathrm{~ms}$ (4 unies in $224 \mathrm{~ms}$ ) to $56 \mathrm{kV}$; the maximum primary capacior charge voluge required for delivering the $200 \mathrm{iV}$ output pulse. Each of the four hith voltage output cables is 100 feet long and nuns along with the convol cable bundle within an electrical steel conduit to the individual unit. This power supply is chosen iecause of its high reliability, compaconess and a singie unit 19 inch rack moant construction. Since a single power supply with four oulpuis is employed, the charge volonge can not be independendy adjused for the four units in the sysem The power supply regulates the primery capacitor charge voluge io $s \pm 0.05 \%$. This regulation is essendal for meeng the $\pm 2.5 \%$ (30) pulse amplitude variation specification.

\section{Thyoum Donal-Puive Trister Oeneratos}

Also located in the contel console are four independent thyratron trigger generators (model MA2169M) manufactured by EEV. Esch of these generacors provide all the pulsed and de vo!tages required for gnd biasing and trigresing of the EEV CX1725X thvratrons employed in the trigger units. A dua-pulse thyratson triggering scheme is used to minimize thyratron conduction jitter. This generator contains 2 line sype pulsers. The PFN providing the preinnization gid (GI) current pulse is chaiged to $-1.5 \mathrm{kV}$. The control grid (GI) voluge pulse is generated by a secood PFN charged to $-3 \mathrm{kV}$. To minimize the $G 1$ and $G 2$ pulse finer each PFN is switched vie a CX1848 glass thvratem swich. No bias voltage is used for thymatron grid GI and the positive poiarity pulse output is applied via a 100 fi RG-58 cable. the connection to the rrid is made via a suitable series resistor at the end of the cable. The grid $\mathrm{G} 2$ pulse is again positive and is superimposed on negetuve $130 V$ bias whxa the trieger gereralor provides. A gain a $100 \mathrm{ft}$ of RG.58 cable with a resistor at the end of the cable applies the pilse to the thymiron grid G2. An extermal trimpot controls the delay between the grid Oi and grid G2 pulse output. This delay adjustment is necessary for oprimizing the thyration jitter characteristics.

Thuratron Trieger Jimer Measuremeat: The four thymoron trigger generators are triggered manually for siogte shot opendion. Rep. rate operation tip to 1 cps is either via ac exterinal is V (<30 ns rise time) pulse or a fiber optic pulse. A uriversal ine interval counter (HP model 5270) was employed for all jitrer measurements reported here. The uring jitter associated with $\mathrm{G}_{2}$ pulse in relation to the fast external electrical srigger input pulse is < $75 \mathrm{fs}(10)$ based on any 10 consecutive shot series. When triggered manually the above jitier increased $100.5 \mathrm{~ns}$ (io). Fiber optic trigerering resulued in this jitter being somewhas higher :han that observed for the e!ectrical trigger mode. A positive drift on the oxder of $0.95 \mathrm{~ns}$ in $\mathbf{G} 2$ puise timing ove? a 100 consecutive shot sequence is obseried for electrical triggering. Jitret between GI and G2 pu'ses is < $0.66 \mathrm{ag}$ peak-tr jeair based on a 100 shot test yequence. For lowest jitter and drift a 30 min warm-up and regulation of $120 \mathrm{~V}$ ac pewer to within $\pm 1 \%$ is necessary.

\section{IRKGGER UNTT HIGH YOLTAGE SECTIOA}

Each of the four tngger units is self contained within a steel enclosure. Figure 2 shows the layour of the trigger unit high voluge section. Each unit utilizes two Maxwell, type-S plastic case. $30 \mathrm{nF}$ capscirors connected in perallel. As shown in Figure 3, a resistor diode nerwork is provided as the input charge feedurough to protect the swriching power supply from capeciter voluge revereals. Th.e primary capacitors charge a Maxwell bigh voluge 0.5 nF capacitor vis a pulse trunsformer. The primery capacilors are swiched by a $70 \mathrm{kV}$ thyratron. The voliage across the $0.5 \mathrm{nF}$ capacitor on the transformer secondacy is inpul to a pulse sharpener via a low inductance connection. The olipil end of the sinarpener is conrected to the $57 \Omega$ output cable via low inductance coaxial feedthrough. Performance of the key high voliage components in the trigger unit are described below.
The DARHT Trigger system specifications require major component life of 107 charge'dixcharge cycies, a tonal syntem jiver ( 3 o) of $\leq 3 \mathrm{~ns}$, and a pre-fire/no-fire rate of 1 in 5000 shots each. This specification could be met only by using a byrauron as the primary switch. The $C X 1725 X$ thyritron manufactured by EEV is chosen tue to its high anode voliage rating and the availability of well documented life and peformance daia. The CX1725X is a rogged 2 gap, hollow anode, thyratron with metai-ceramic envelope. It is supplied with an extemal decade box to precisely control the heating of the reservoir filment which controls the gas pressure inside the tube. This version of the thyratron makes the optimization of the tube performance eary: especially as the tube ages.

Dyyratron hearer dc power supplies: To minimize shyratron conduction jitter, separate linear di power supplies $(< \pm 0.1 \%$ voluge regulation) are used for the cathode and reservois heater fiamerits. The cathode heater is operated at $6.6 \mathrm{~V}$ with the reservoir voluge maintained at $6.3 \mathrm{~V}$. The curren:s diawn by the cathode and reservoir filements are $45 \mathrm{~A}$ and $7 \mathrm{~A}$ respectively $\mathrm{A}$ considerable effort had to be expended to protect the low voluge dc suoclies (including the de reset supply) from the fast voltage transients associated with thyretron switching (very high $\mathrm{d} / / \mathrm{dt}$ ). Prosection as shown in Figure 3 is proviked in the form of LC fliters and bypass capacitors. Each de scpply, in addicon, is provided with a fast protection circuit consisting of various capaci:ors, MOV. and trassorb directy across the ourput terminals.

Devratron voliare hold-off: Thyratron anode voltage hold-off and gas pressure is optimized using the inyratron extemal decade box. Different settings allow the reservoir fildment healet current to be controlled in fine discrete sieps. Lowering the current through the reservoir heater (by lowering the shuat resistance value afplied across the heater by the cecade box) redictes gas pressure. This increases the anode hold-off voluge since the rute operaites on the left hand portion of the Pasctien's curve. The CX:725X relizbly hoids-off a maximum anocle voltage of $63 \mathrm{KV}$ under the charging conditions associated with the trigger units. This vollage exceeds the maximum $56 \mathrm{kV}$ charge reouired for delivering the $200 \mathrm{kV}$ ousput pulse. Even with the lowest gas pressure setting ullowed by the exierral decade bux (libe practically starved of gas) the thyratron pre-fired after a few seconds above $63 \mathrm{kV}$ charge. In an effort to improve the de toldi-off voltage performance, the thyratron. gradient grid biasing, shown in Flgure 3, was changed from its recommended 50\%/50\% value. The voltage biasing ratio of the anode 10 gradient grid acd andient grid to cathode was changed to $40 \% / 60 \%$ and subsequently to 60\%/40\%, respectively by appropriately changing the resistor valces in the gradient grid biasing resisura chain. Both these vollage grading sigrificantly deteriorated the thyration hold-off voltage compared $w$ the s0\%/50\% gradient grid biasirg. The $40 \% / 60 \%$ biasing, being the worst, reduces the hoid-off to $<60 \mathrm{kV}$ even at very low gas pressures. The gradient grid is thus carefuily biased at half the anode voluage using $1 \%$ precision high voltage metal oxide resistors.

New thyratrons exhibit a conditioning effect. All tubes are conditioned by redicing the gas nibe pressure is the minimum aliowed by the external decade box serungs and applying a few hundred shots at $63 \mathrm{kV}$. The tube is considered conditioned if it wittstands a 1 minule de high-pot test and no more conditioning shoes are applied. This conditioning ensures that the tube reliably hoids the maximum required crarge voitage of $56 \mathrm{~kW}$. As shown in Table 1. no pre-fires or no-fires were present in the 5000 consecutive shor test sequence at $0.2 \mathrm{~Hz}$. This ciearty demonsintes the inherent relisbility of the trigger units.

Thyratron discharge curiesil: The toliow anode configuration successfilly conducts large reverse curtenis. Figise 4 shows the thytatron discharge current when a 3 liH output iaductor iocated from the pulse sharpener output to ground is used for determining the effect of de reset on pulse sharpening. This inductor provides a convenient way to reset the puise shappener ferrites usicg the same 

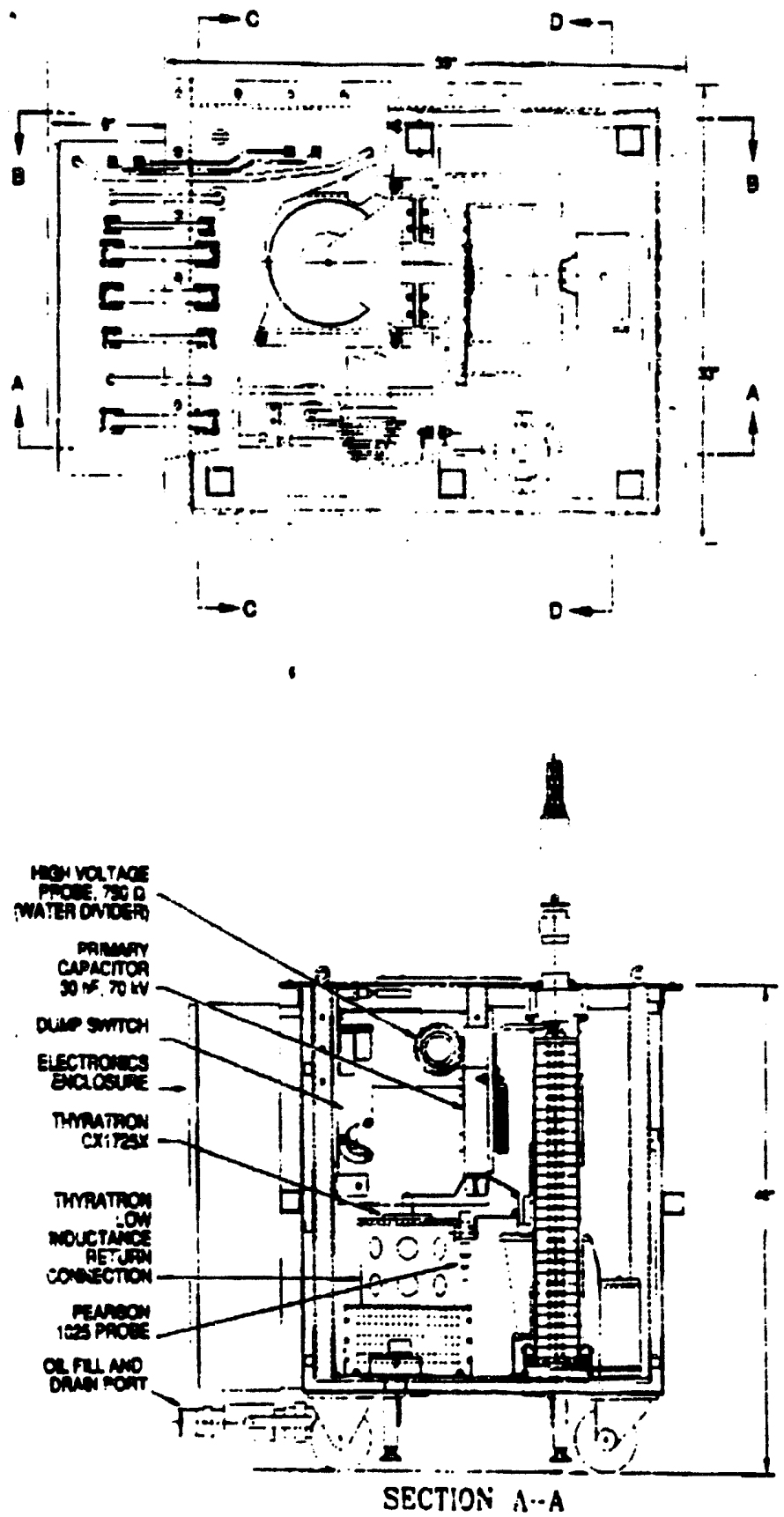
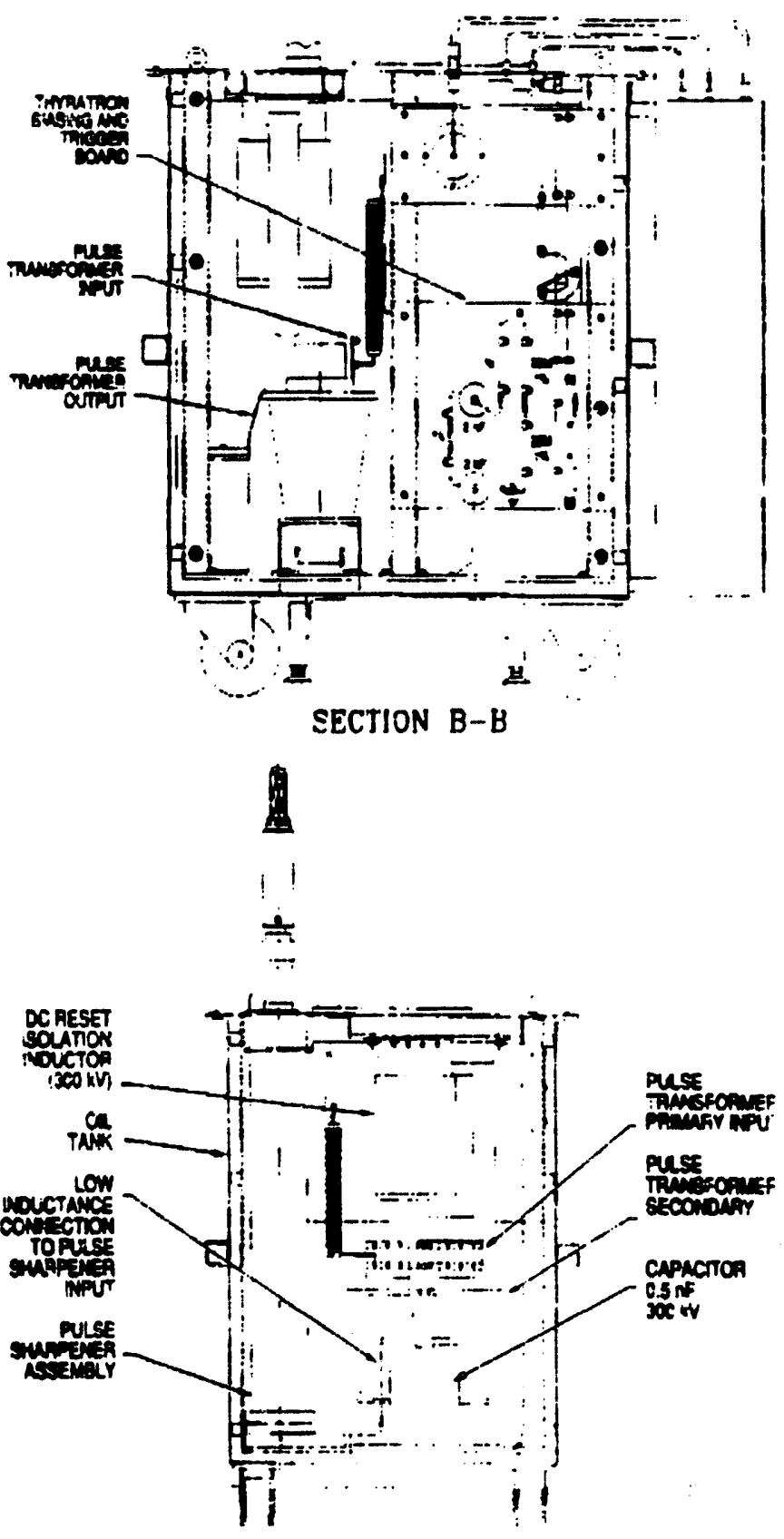

SECTION D-D

Fig. 2 Section views of trigges unt abowing component layout

constunt current reset supply ( $-60 \mathrm{~A})$ used for re-setting the polse trensformer. Reset in this case is applied on the transformer secondery winding and requires a reset power supply isolation choke (2 mH. $300 \mathrm{kV}) \mathrm{s}$ shown in Firwe 3 . The 3 uH inducto (not shown in Figure 3) provides a parllal pes for the reset currene. The net reset curreat resistively divides between onnsformer secondary resistance and the $3 \mu \mathrm{H}$ indoctor resintunce. The resistance of the $3 \mu \mathrm{H}$ inductor was tolored 20 is 10 allow at lent $20 \mathrm{~A}$ of reset curreat to dow in the pulce unndocmer wioting. The reset curreat for the pulse sherpener in this case is $-35 \mathrm{~A}$. The thymoton peak discharge current in the forwand direction is $16 \mathrm{kA}$ with a curreat reversil peat of $12 \mathrm{kA}$. Several thousand of such 75\% reversal tinging current pulses have been applied to the thyratron during the testing of the first trigger unis the hollowanode CX1725X hes been subjected to a maximum forward peak curreat of $20 \mathrm{kA}$ with $75 \%$ current reversal for few hundred shots. The thyratron successfully survives these current discharges with no deterionation observed in its performence.

\section{Brimiound Secondirry Capacion}

Two 30 af capacitors are used in the primary circuit to minimize the woll primiry circuit inductance. The capeciton (model 35158), rated at $70 \mathrm{kV}$ and $20 \%$ voluge reversal, have been apecifically designed by Mexwell capacitor depurtment to provide life $>10$ ? cherte/discharge cyclem. The sincle exiended foil capacitor is 2.3 inct $\times 5.9$ inch $\times 15.5$ inch high.

A $0.5 \mathrm{nF}$ Maxwell double-ended capacitor is used on the palse tunformer recondary. The capacitor (model 35147), rated at 300 kV and $20 \%$ voluge reversal, is again cesigned for a life $>10^{7}$ chire/discharge cycles. This capacitor is 4 inch $\times 6$ inch $\times 8$ inch high in overall dimeasions and assists in yielding a higher volue as the pulse shupener inpot. The input voltage peax amplitudes are $-10 \%$ higher with $0.5 \mathrm{nF}$ capacitor at the transformer secondary compered to the case when it ls absent. Higher input voltage of the 


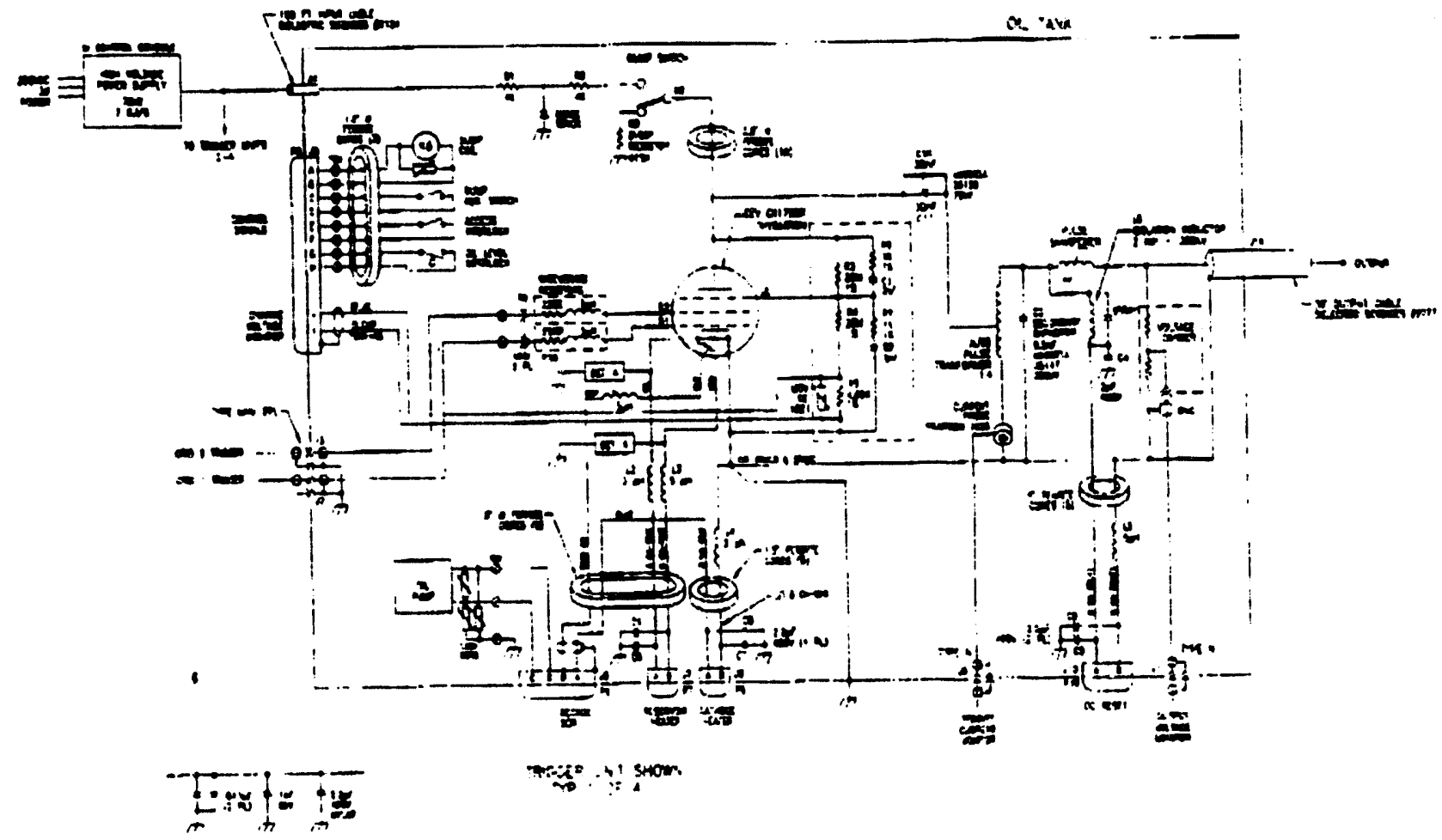

Fig 3 Eiecancai scrematic of trigger unit higì voltage section

pulse sharpener increases reliab:lity since :ower charge voltage is required for genertiag be same 2 (i) $\mathrm{k} v$ pu.se. Ai chinge voltages of $30 \mathrm{kV}$, the ourput plise voltage :s $-i 9 \%$ tigher whice at $63 \mathrm{kV}$ the output pulse voltage is $-13 \%$ highes with the $0.5 \mathrm{nF}$ capicito? present on the transformer secondary. Addition of inis capacitor on the pulse transformer recondary, bowever, slows the rali nime (10\% to $90 \%$ ) of the pulse sharpener infit from 52 as to 100 ns. Tais slowing of the pulse. bowever, does not have a noticeable effect on the fali time of the puice sharpener output pulse as shown later.

\section{Bulse Tarnsioner:}

A Stargenes :ron-core pulse auto-ransformer (moste! S: 7638) jesigned for DARHT steps-up the primary capacitor voitage. The leakage inductance of tiis transforme!, with a 2 rum primary and 8

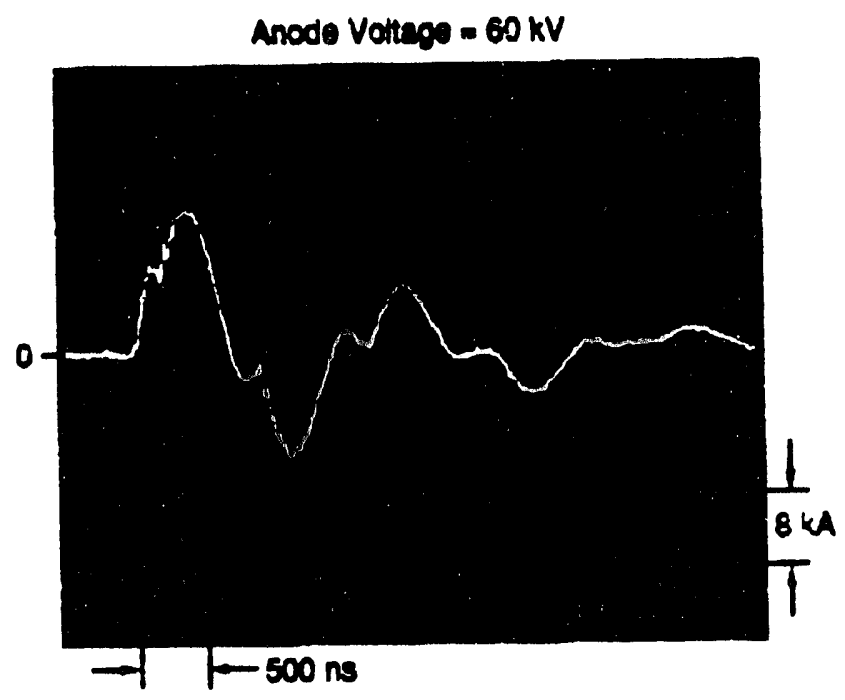

F:g. 4 Thyratron cirrent waveshape with $75 \%$ reversai tum secondary, measures $195.5 \mathrm{riH}$ at $1 \mathrm{MHz}$ referred to the primary winding. The magnetizing (self) inductance at $1 \mathrm{MHz}$ is $252 \mathrm{HH}$ reierred to it.e secondary winding. The transformes secundary is rated for $300 \mathrm{kV}$. The overali dimensions of this pulse transformer are is inch $\times 9$ incii $\times 18$ inch high. A single $2 \mathrm{mH}$. $300 \mathrm{kV}$ chote $(60 \mathrm{~A}$ de rating) is used to reset the trinsformer. Reset on the secondary winding (instead of the primary) enables the use of a single dc rese: supply for both the transformer and the pulse sinapener. The trunsformer requires at least is A of reset current when the sore is being reset from the secondary winding. Larger number of secondary ( 3 insiead of 2) turns belp in using 3 iower wattage power xupply whose size is also small. This, however. comes at the expense of a lisge isoiation inductor rated ior transformer secnndary volage.

The presecoe of the pulse sharpener infiuences the net voliage step. up ratio depending on the charge voltage. 5or a cliarge voliage of 30 $\mathrm{KV}^{\prime}$ the total voliage ring-up factor delermined from the measured ransformer secondary vollage is 4.26. This factor drop3 10 $3.38 \mathrm{al}$ charge voltage of $60 \mathrm{kV}$. These factors are for the casc with the $0.5 \mathrm{nF}$ capacito present at the uransfcrmer secondary and the pulse sharpener being reset (current $-35 \mathrm{~A}$ ) using the $3 \mathrm{HH}$ outplit inductor. Ring-up factors are lower when the $0.5 \mathrm{nF}$ capacitor is cot used. Pulse shamener outpul voltage is higher in the absence of the $3 \mu \mathrm{H}$ ouput inductor.

\section{Pinke Shrupenet}

The voluge appearing at the $0.5 \mathrm{nF}$ capacitur on the transformer secordary bas a iall :ime (10\% to $90 \%)$ of $-100 \mathrm{~ns}$. The fall time of this pulse is sharpened using the pulse sharpener prior to being delivered to the laad via the $67 \Omega$ coasual output cable.

The puise sharpener is a ferrite flled coaxial unsmission line as shown in Figure 5. The inner 1.5 inch O.D. aluminum conductsr is surrounded by 29 ligh frequency nickel-rinc ferrise toroids (Ceramic Magnetics C2010) with a 1.51 inch I.D., 3.98 inch O.D. and 1 incb ihickness. The outer diuminum conductor of the innsmission line surrourding the ierrites has a 4.25 iach I.D. This ferrice filled transmission line is supported vertically by a Lexan piate atiacted at the botom of the outer conductor. The ine is transformer oi: insulated and adapts io a $67 \Omega$ high voltage catle at 


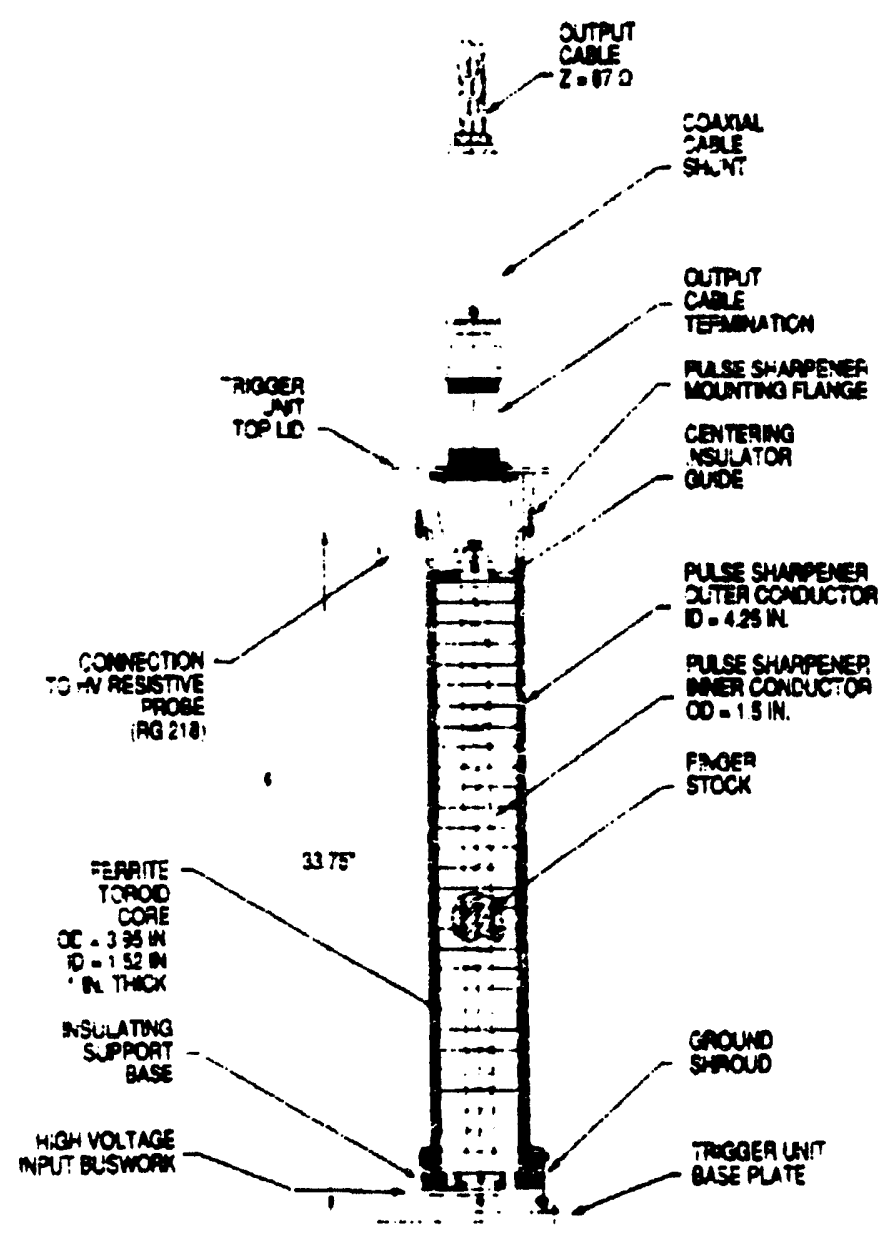

Fig. 5 Pulse shappenes details

its output via a specialiy designed (Isolaton Desim model D-108MS) low inductance coaxial feedthrough. A cable (resistive) curren: shunt (T\&M Revearch mode! LF. 500-2-.MAXN) located a the feedthrough output monitors the output pulse clisent. A fast esponse water divider probe, shown on figure 6, connected at the junction of the pulse sharpener and the cable feedthrough measures the fall time and amplitude of the pulse injected in:to the $67 \Omega$ cable.

The material composition of the ferrites csed in the hine is a rey parameter in producing pulse shapening. Eartier experiments at Maxwell demonstruted that ferrites witb $\mathrm{Mn}_{\mathbf{2}} \mathrm{Zn}$ composition periorm very poorly compared to Ni-Zn compositon.

\section{DARHT TRIGGER SYSTEM TEST RESUTTS}

\section{Tripere Syrtem litter Pefiomance}

Time Interval Counier (HP model 5370 ) is used to mensure the wod system jitter. A fasi low volage (zero-time trigser with $<30$ po peris-to-peak jitrex) signd from LANL REMOTE console sturts this counter. The counter is stopped asing the output pulve signal from the high voltage resistive ( 750 Q) probe. The counter START and STOP levels are set a $50 \%$ of the respective signd peata.

Dind-pulse triggering of the thymaton erids is the key to obonining the lowest system jiecer. The pre-ionization (G1) current peak. control grid (G2) puise delay, and nate-of-rise of $\mathbf{G 2}$ polse bave to be optrmized for obiaining low jitter. The optimization involves adjusting the grid $G_{2}$ pulse delay and redocing the peak curnent of the grid $G 1$ pulse to < $5 A$, as shown in Figure 7 . The peak current is reduced by proper selection of ihe restistor at the ootput end of Gi pulse cable. A $220 \Omega$ wire wound (3 $\mu \mathrm{H}$ inductance) resistor proved suitable. Witt $G$ I pulse inreni peak exceeding $5 \mathrm{~A}$, the CXI725X always fires on the grid GI pulse when the mode voluge exceeds $45 \mathrm{kV}$. Thyontron firing from GI pulse increases the

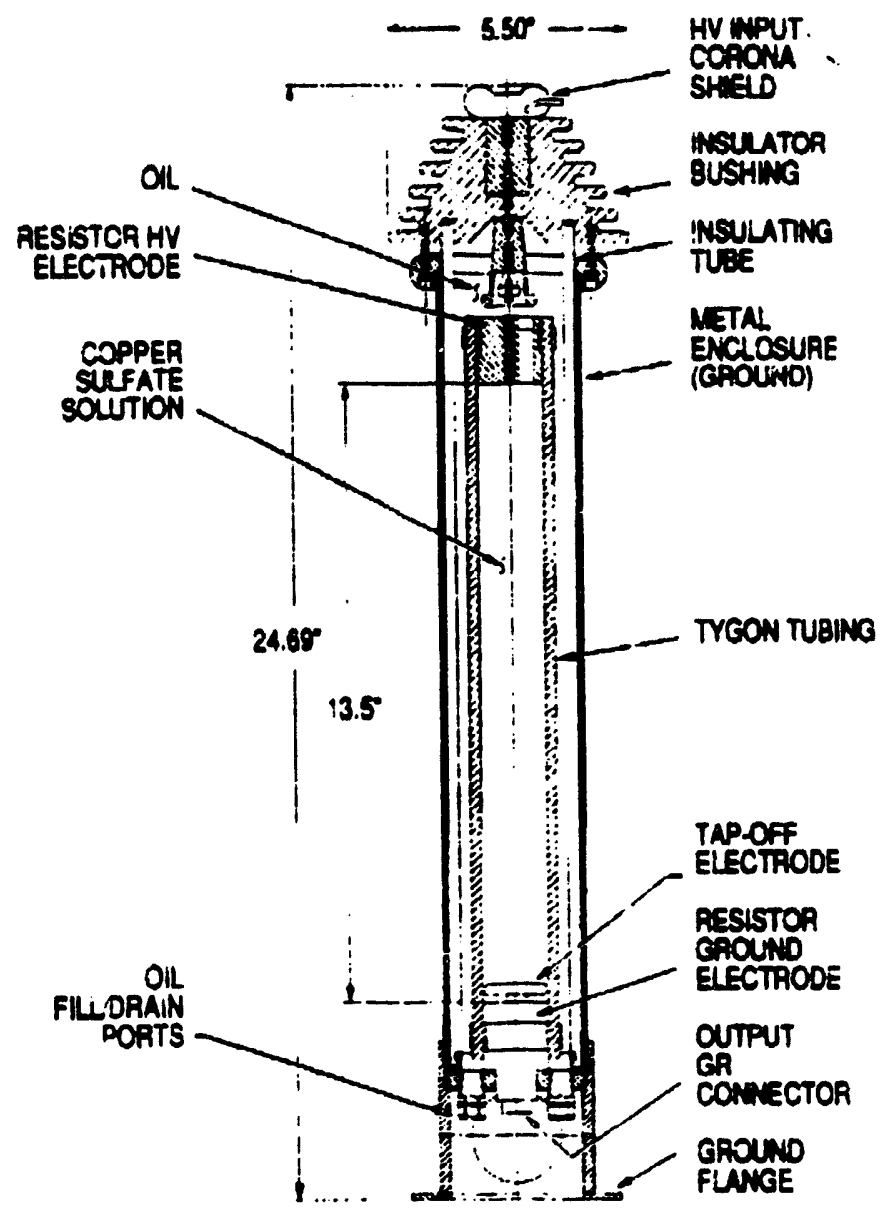

Fig. 6 Fast response resistive water probe

system peak-to-peak jitter very significan:iy compared to the case wheo it fires from the delayed $(-800 \mathrm{n}, \mathrm{s})$ grid 02 pulse as shown in Figure 7. The measuremenis aiso reveal sat the jicter is higher at lower tiyrauren gas pressures. For a fully optirized thymaron and its Cuni-pulse trigger. DARHT Trigge: Sysiem jituer of < 275 ps (10) based on 100 consecutive shots at full output voltage has been achieved. The cortesponding peak-10-peak Trigger System jitter is $<1.5 \mathrm{as}$. System jituer at lower outpur voluge range are no differen: from those at the highesi level. To achieve the 1.5 ns pesk-to-peak rigger syster jitter it is exuremely important to regulare the $110 \mathrm{~V}$ $a c$ input to the dc supplies and the thyraton trigget generators to $\pm 1 \%$.

With the srid G: pulse current peak $>3 \mathrm{~A}$, the jiner above $45 \mathrm{kV}$ anode voluge is $>2 \mathrm{ng}(10)$. The waveforms recorded for erid $G 1$ and $\mathbf{6 2}$ pulses for this case cleariy indicace that the thyrarun fire: trom the grid $G 1$ pulse soon after the pre-ionization current exceeds $5 \mathrm{~A}$. For anode voltage < $45 \mathrm{kV}$ and pre-ionization current peak as high as $18 \mathrm{~A}$ the thyratron fires correctly from the grid 62 pulse 2.20 the jitter is similar to thoce reporied above for the optimized sysierr.

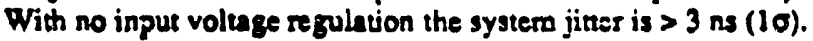

\section{Pulee Shucoeneer Periomennce}

Electrical faiiure of the puise shargener occurs in form of surface trackisg initinting at the fertix-oil ed pe on the I.D. of the core. The track runs radially ourward berweer adjacent ferrite surfaces iowards the outer conductor. Tracking has been observed when electric fields at the ferrite-oil interface exceed $500 \mathrm{kV} / \mathrm{cm}$. This value is very similar to breaicdown strength of transformer oil calculated from the well known J.C. Marin's breakdown equation:

$$
E_{b}=500 t^{-1 / 3} A^{-0.1} \mathrm{kV} / \mathrm{cm}
$$

for positively charged surface. Here $t$ is the eifective time in $\mathrm{Hs}$ for 


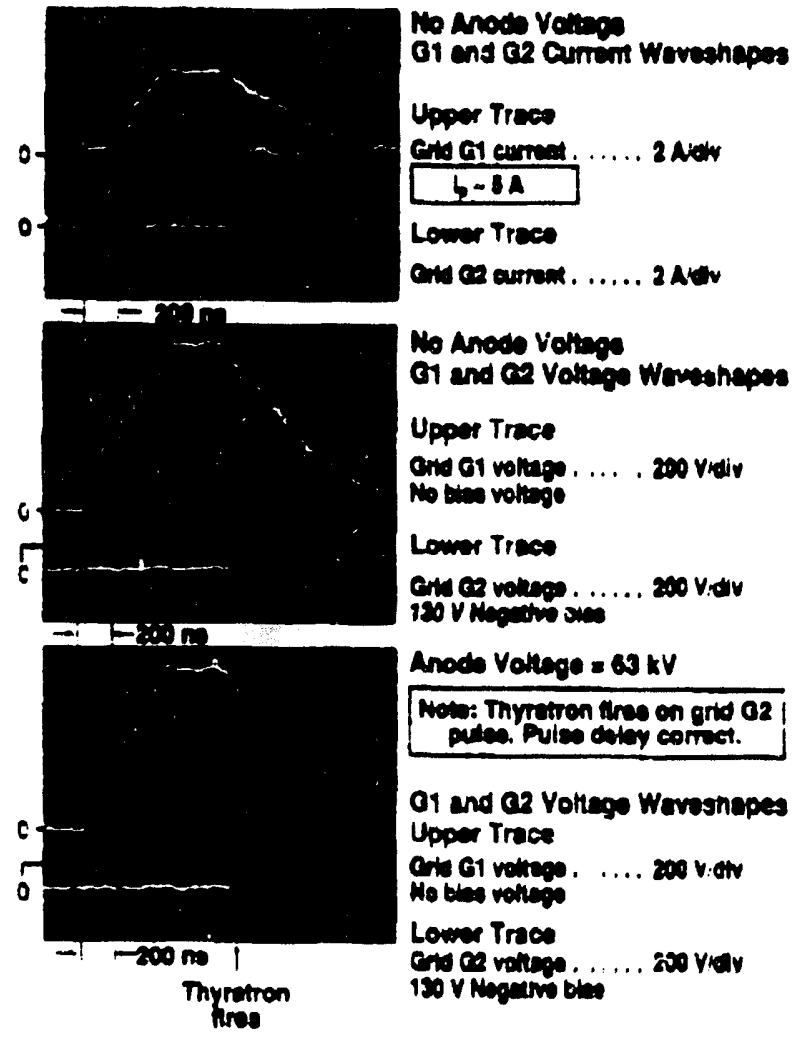

Fig. 7 Optimized tual-pulse trigzers for CX1725X Lilyratron

which the volage exceeds $63 \%$ and $A$ is the stressed ara in $\mathrm{crt}^{2}$. The use of firger stock between the p'lse sharpener innet conductor and the edges where the adjacent ferrite core surfaces are in contact led to a superior perforwance. Presence of aur bubtles, as with any otber high voluge sysum, is very devimental in the voluge holdoff of the sulse shamener. All output pulse wavesinapes reporred below are reconded using the water probe stown in Figure 6.

Figure 8 shows the inpit and output waveshapes recorcied for the pulse sharpener at a charge voluge of $60 \mathrm{kV}$. In this case the pulse shappener has a $30 \mathrm{~A}$ de resel applied vie the $3 \mu \mathrm{H}$ inducior ccnnected at the ourput. The plibe sharpening effect is clearly evident. Voltage reversals at the input are atso evident waich are a result of the inductor present at the pulse shaperer outpit. As seen in the wave?orms, reverse input vollages swings are also plise shappened. The inpul pulse fall time (10\% to $90 \%)$ of $100 \mathrm{~ns}$ is shapened to -12.5 ns. Pre-pulse on the output palse is nezligible.

Figure 9 shows the output pulse waveshapes recorded when the inpul fulse ?all ime is reduced from 100 ne 1052 ns by removing the $0.5 \mathrm{nF}$ capacitor. The shapener has a $35 \mathrm{~A}$ reset. It is evidem thas the ptise ou:put fell time at $63 \mathrm{kV}$ is similer to tha: of the eur!:er case where the inpul puise fa!! time is 100 ns. Two things to be noted from this figure are that the output pulse arrives carlie: in time and pulse starpening improves as the charge voltage increases. Pulse sharpening in this pulse starpenet design was very poor very poor below $25 \mathrm{KV}$ charge.

Finally the the effect of no reset appiied to pulse sharpener is thown in Figure 10. For this case the $3 \mu \mathrm{H}$ induccor at the output of the pulse st.appener is remored. The $0.5 \mathrm{nf}$ capacitor is present on the tansformer secondary and the pulse onnsforme: reset current is 16 A. As shown in this figure the outpli pule fall times are not very different from the case where the pulse snarpener has \& 30 A reset. Not only does the pulse sharpening remain unaffected, bus also ihe output voltages are the highest of any case. This is due to the fact that the oumut inductor loads the pulse shapener output. Maximum outpus voilage of $232 \mathrm{kV}$ with a fall time of $-i 3$ is is measured at starge voluge of $63 \mathrm{kV}$. As shown in F:gure !1 no current or output voltage reversals are present with the $3 \mathrm{HH}$ inductor removed. This figure also shows the ourplit puise waveshafe as econded by the cable shune. It is clearly evideni tiat the shunt rias a very noisy response.
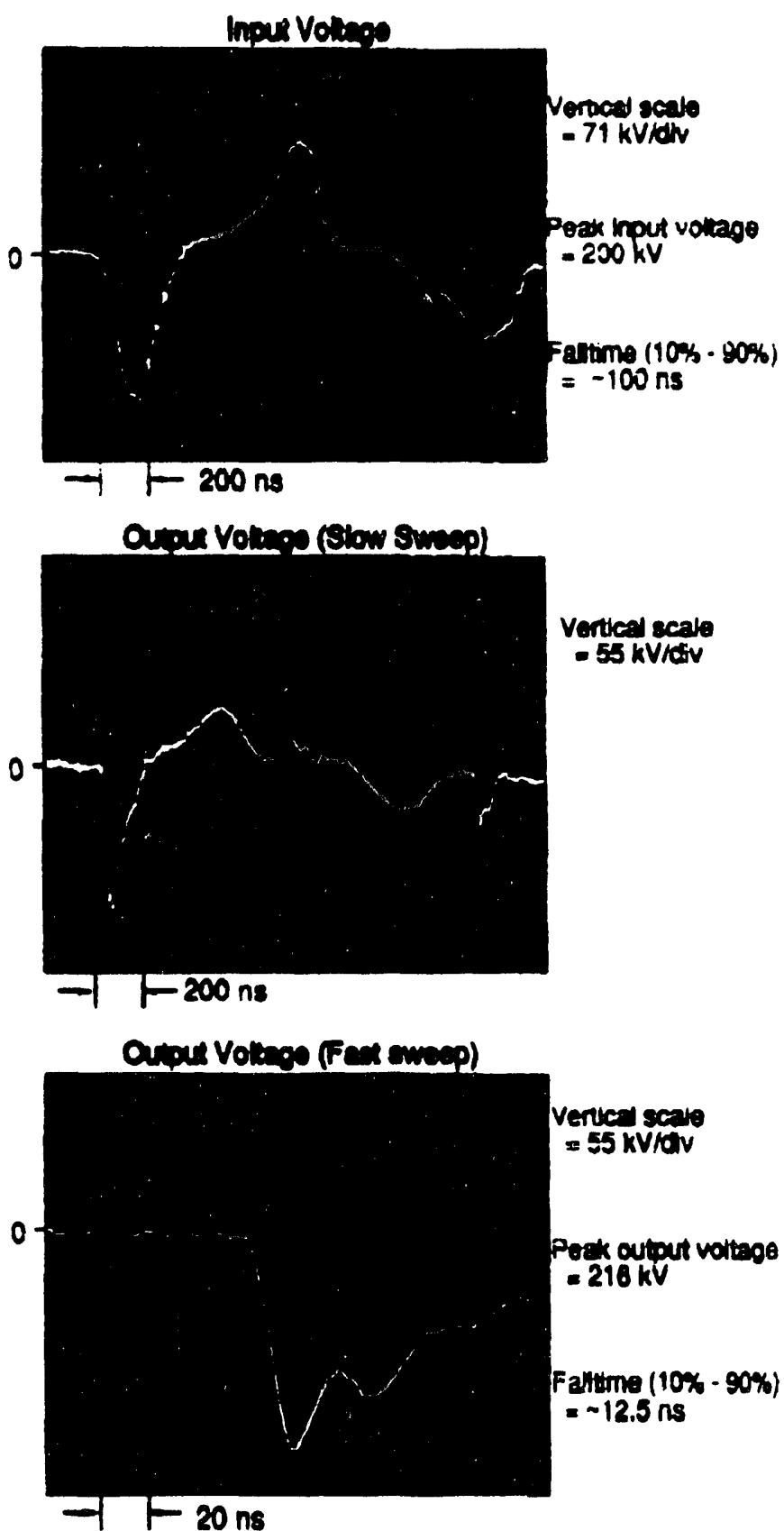

Fig. 8 Pulse shappener input/output waveforms (30 A reset) 


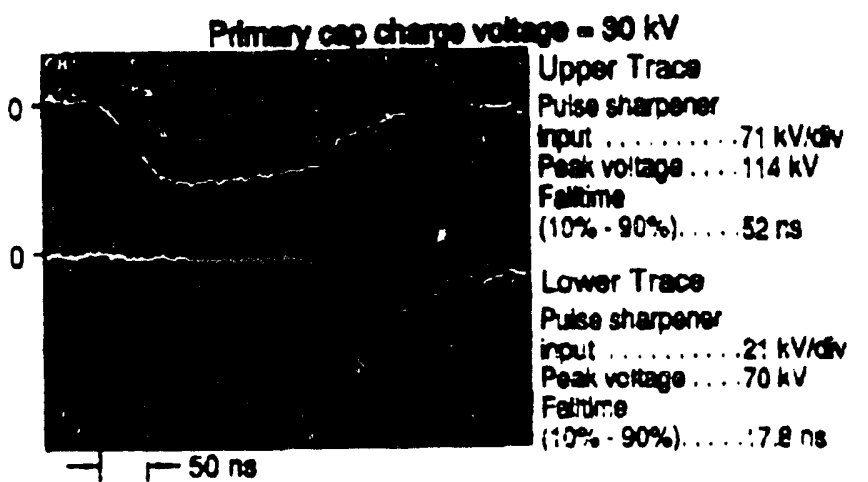

Pitney cep chares volies - $50 \mathrm{KV}$
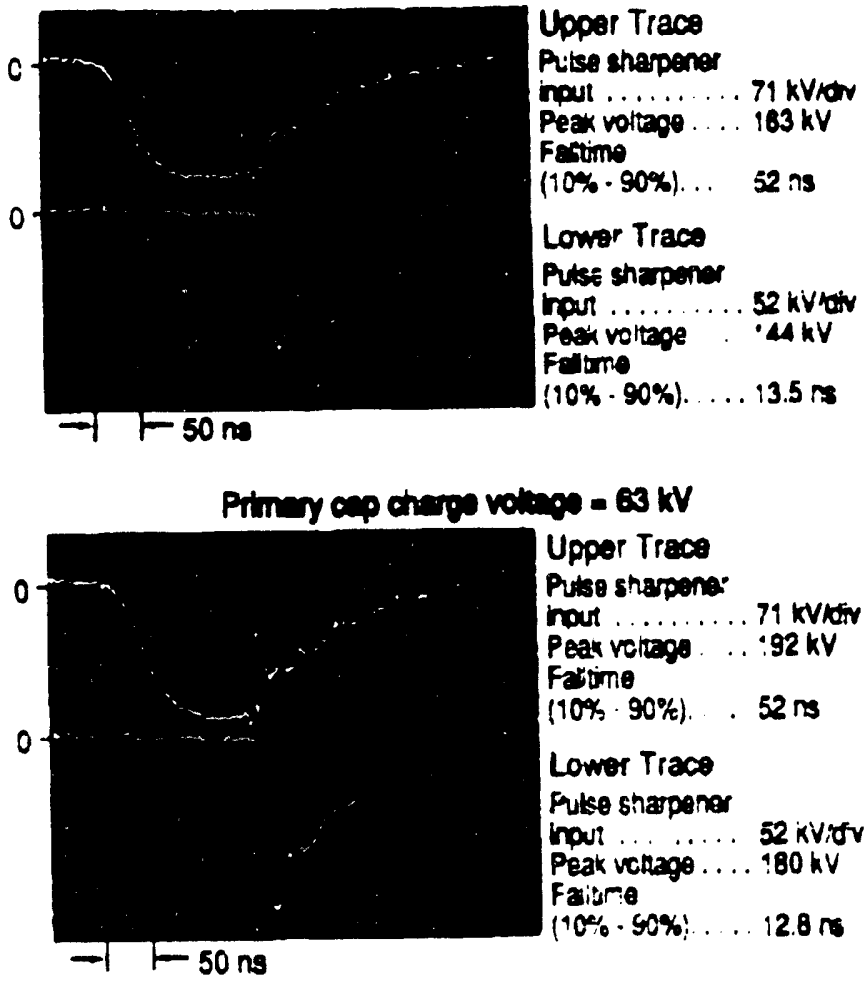

Fis. 9 Pulse sharpener inputroutput waveforms without $(0.5 \mathrm{nF}$ sapacitor. Input pulse fall umes now $52 \mathrm{~ns}$.

\section{CORiCLUSIONS}

The protoxype DARHT Trigger System exceeds all design goals and specifications. As demonstrated by extensive acceptance testing of four units at Maxwell, this type of trieger system is capable of providing $200 \mathrm{kV}$ voluge pulses with $\mathrm{dV} / \mathrm{dt}>15 \mathrm{kV} / \mathrm{ns}$ into $67 \Omega$ coaxial cable load. The extreme reliability of this design is demonstrated by very low pre-fire/no-fire probability of $\ll 0.02 \%$. Exiremely low system peak-to-peak jitler of < $1.5 \mathrm{~ns}$ and lorig maintenance free life makes trese thyratron-transformet-sharpenet based higin voltage fas rise time puiven very stusucjue.

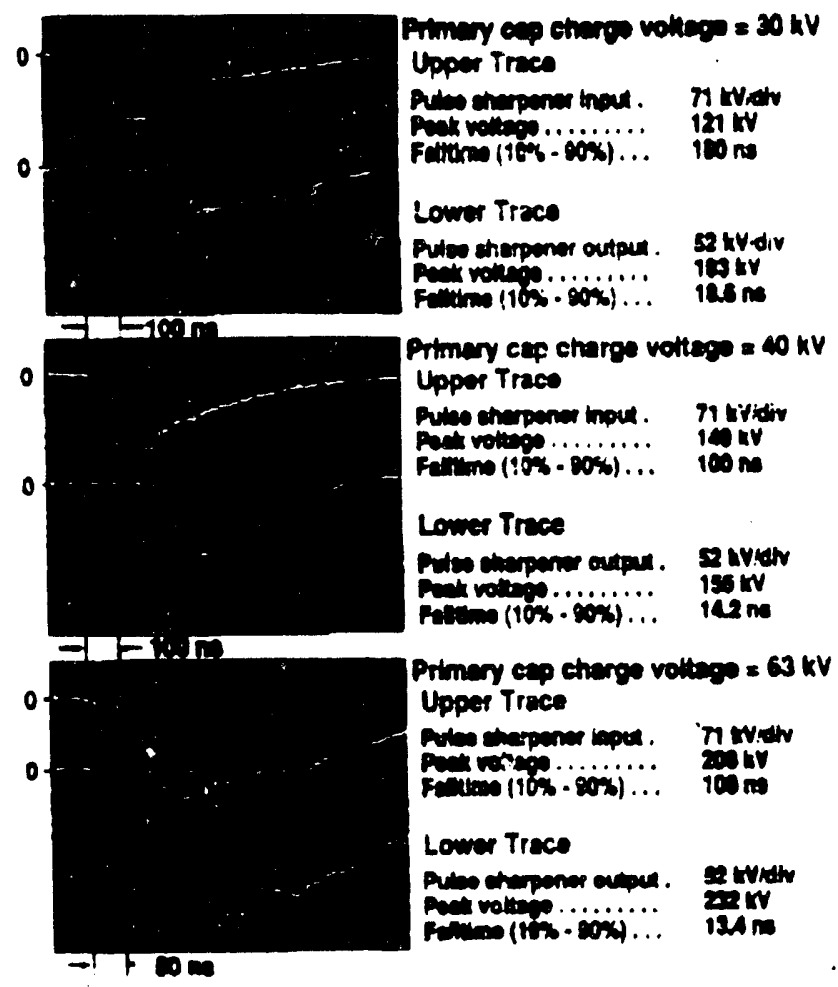

Fig. 10 P.ulse sharpener inpuloutpur waveforms without $3 \mu \mathrm{H}$ inductor (no reset). $0.5 \mathrm{nF}$ capácitor present.

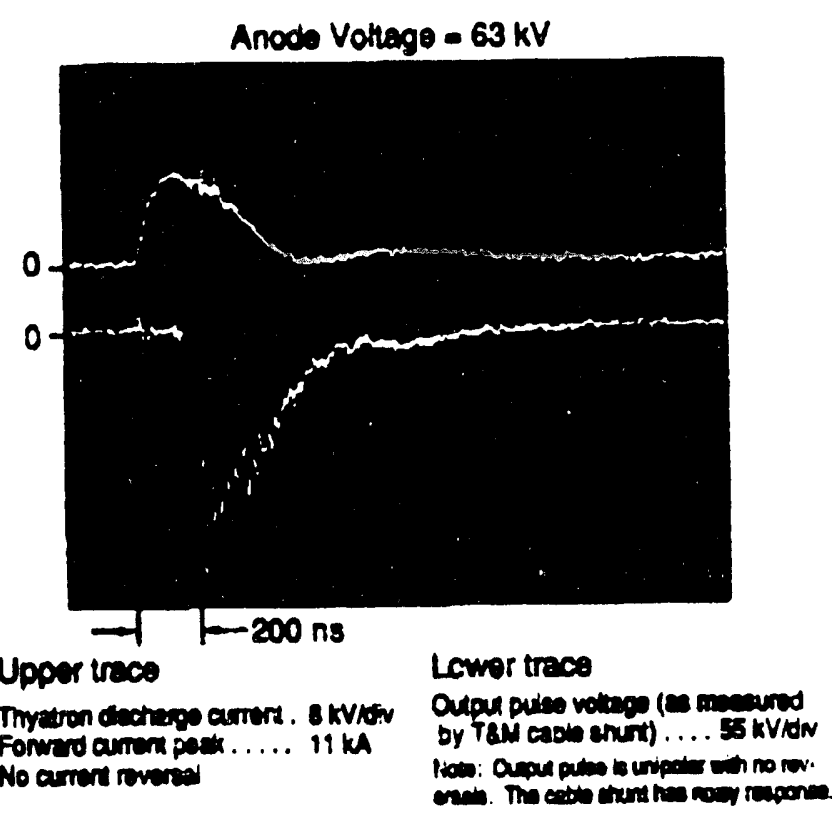

Fig. 11 Thyratron cirrent withuut $3 \mu \mathrm{H}$ inductor and oupu: puise voluge as recorded by T\& M cable shunt.

\section{ACKNOMIIDDGEMENTS}

The authore thank Dr. Y.G. Chen for his lechnical assiunance. support and encourngement during the course of this program. Thantes are also due to Mr. Richard Johnson. Cocsultant, who helped extensively in designing the control rystem.

- LANL Subconjact No. 9-LFT-M9242-1

+ Preseatly at Direcied Technologies, Inc., San Diego, CA 92121 
